\title{
The effect of formaldehyde or glutaraldehyde application to lucerne before ensiling on silage fermentation and silage $\mathbf{N}$ digestion in sheep
}

\author{
By R. C. SIDDONS, C. ARRICASTRES, D. L. GALE AND D. E. BEEVER \\ The Grassland Research Institute, Hurley, Maidenhead, Berkshire SL6 5LR
}

(Received 2 September 1983 - Accepted 19 April 1984)

1. The primary growth of lucerne (Medicago sativa) was ensiled after treatment with either formic acid alone
(4.1 litres/t; silage F) or with formic acid and either formaldehyde $(30 \cdot 5 \mathrm{~g} / \mathrm{kg}$ crude protein (nitrogen $\times 6 \cdot 25 ; \mathrm{CP})$;
silage FF), glutaraldehyde ( $44 \cdot 2 \mathrm{~g} / \mathrm{kg} \mathrm{CP}$; silage $\mathrm{FG}$ ) or a mixture of the two aldehydes at approximately half
their individual application rates (silage FFG).
2. Compared with formic acid alone, both formaldehyde and glutaraldehyde reduced protein breakdown and
carbohydrate fermentation during ensiling. The extent of protein protection afforded within the silo was similar
for the two aldehydes, whereas formaldehyde was more effective in restricting carbohydrate fermentation. The
effect of treatment FFG on silage fermentation was confounded by the silo bag bursting and the development
of a clostridial-type fermentation. All aldehyde treatments reduced silage soluble- $\mathrm{N}$ content but $\mathrm{N}$ disappearance
when the silages were incubated in polyester bags in the rumen was high for all silages and reductions due to the
aldehydes were small.

3. Silage digestion was studied in four mature sheep each fitted with a rumen cannula and re-entrant cannulas in the proximal duodenum and distal ileum.

4. The apparent digestibility of organic matter $(\mathrm{OM})$ in the whole tract was reduced $(P<0.05)$ to a similar extent by both aldehydes, whereas rumen OM digestion was reduced $(P<0.05)$ more by glutaraldehyde than by formaldehyde. The effects on digestion appeared to be due to the action of the aldehydes on the foods rather than to any adverse influences of the aldehydes on the metabolism of the rumen microbes because, although rumen ammonia levels were lower $(P<0.05)$ when the aldehyde-treated silages were given, rumen casein-degrading activity, the degradation of different feedstuffs when incubated in polyester bags in the rumen and microbial $N$ flow at the duodenum did not differ $(P>0.05)$ between silages.

5. All aldehyde treatments decreased $(P<0.05)$ the apparent digestibility of $\mathrm{N}$ in the whole tract. Silage $\mathrm{N}$ degradability in the rumen was also decreased $(P<0.05)$ from 0.82 for silage $F$ to $0.67,0.60$ and 0.62 for silages FF, FG and FFG respectively, and consequently non-ammonia-N (NAN) flow at the duodenum increased $(P<0.05)$. The aldehydes did not adversely affect the apparent digestibility of NAN in the small intestine, and net NAN absorption from the small intestine increased from $8.8 \mathrm{~g} / \mathrm{d}$ with silage $\mathrm{F}$ to $11.4,15.3$ and $14.2 \mathrm{~g} / \mathrm{d}$ with silages FF, FG and FFG respectively. Both the decrease in $\mathrm{N}$ degradability in the rumen and the increase in net NAN absorption from the small intestine were greater $(P<0.05)$ with glutaraldehyde than with formaldehyde.

When forages are conserved as silage without additive treatment, much of the herbage protein is degraded to non-protein-nitrogen, whilst soluble carbohydrates, which would otherwise serve as a source of readily-fermentable energy for rumen microbes, are fermented to short-chain organic acids. When such silages are consumed by ruminants, the rate of ammonia production in the rumen far exceeds its rate of assimilation by the rumen microbes. Most of the excess ammonia is absorbed from the rumen and a large part is excreted as urea in the urine, resulting in an inefficient utilization of silage $\mathbf{N}$ (Wilkinson et al. 1976).

Improvements in silage nutritive value have been achieved by the use of formic acid as a silage additive (Waldo et al. 1971), but this is mainly due to its ability to prevent clostridial fermentation and reduce carbohydrate fermentation within the silo. Although it reduces the rate of proteolysis in the silo (Carpintero et al. 1979), its ability to reduce protein degradation in the rumen is minimal (Chamberlain et al. 1982; Siddons et al. 1982). Formaldehyde has also been used as a silage additive (Wilkins et al. 1974; Wilson et al. 1974), both for its bacteriostatic properties in reducing silage fermentation and for its ability 
to protect protein from degradation in the silo and in the rumen. Marked reductions in the rumen degradability of silage $\mathrm{N}$ and increases in protein flow to the small intestine in response to formaldehyde treatment have been demonstrated (e.g. Siddons et al. 1979). However, if the level of formaldehyde application is too high, microbial growth in the rumen and protein digestibility in the small intestine are adversely affected (Beever et al. 1977), and the need to control carefully the level of application would appear to be a major limitation to its use as a silage additive.

The studies of Mangan et al. (1980) suggested that glutaraldehyde may offer certain advantages over formaldehyde as a silage additive. Glutaraldehyde was found to be more effective than formaldehyde in the fixation of isolated chloroplasts, it reacted more rapidly with protein and did not affect protein digestibility. Furthermore, in cattle given lucerne (Medicago sativa), which had been treated with formaldehyde $(114 \mathrm{~g} / \mathrm{kg}$ crude protein $(\mathrm{N} \times 6.25 ; \mathrm{CP})) 48 \mathrm{~h}$ before cutting, ciliate protozoa and motile bacteria in the rumen were immobilized, whereas in cattle given lucerne treated with glutaraldehyde $(190 \mathrm{~g} / \mathrm{kg} \mathrm{CP})$ there was no corresponding effect.

The present study was undertaken to compare the effects of formaldehyde and glutaraldehyde, when applied in conjunction with formic acid to lucerne before ensiling, on silage fermentation and on the digestion of silage $\mathbf{N}$ in sheep.

\section{EXPERIMENTAL}

\section{Silages}

The primary growth of lucerne was cut on 9 June 1980; approximately $4 \mathrm{~h}$ after cutting it was harvested with a precision-chop forage harvester and approximately $3 \mathrm{~h}$ after harvesting it was ensiled. During harvesting the lucerne was treated with either $4 \cdot 1$ litres formic acid $(850 \mathrm{~g} / \mathrm{kg}) / \mathrm{t}$ (silage F), 4.4 litres formic acid and 3.64 litres formaldehyde $(350 \mathrm{~g} / \mathrm{kg}) / \mathrm{t}$ (silage FF), 3.9 litres formic acid and 3.65 litres glutaraldehyde $(500 \mathrm{~g} / \mathrm{kg}) / \mathrm{t}$ (silage FG) or 4.2 litres formic acid, 1.95 litres formaldehyde and 2.28 litres glutaraldehyde/t (silage FFG). The additive mixtures were diluted with water such that a similar volume $(8 \cdot 4$ litres/t) was applied in all cases. The aldehyde-containing additives contained Tween 20 $(1 \mathrm{ml} / \mathrm{l})$ as a wetting agent and rate of application was equivalent to approximately $1 \mathrm{~mol}$ aldehyde radical $/ \mathrm{kg} \mathrm{CP}$, i.e. $30.5 \mathrm{~g}$ formaldehyde $/ \mathrm{kg} \mathrm{CP}$ (silage FF), 44.2 glutaraldehyde $/ \mathrm{kg}$ $\mathrm{CP}$ (silage FG) and $16.4 \mathrm{~g}$ formaldehyde and $27.7 \mathrm{~g}$ glutaraldehyde $/ \mathrm{kg} \mathrm{CP}$ (silage FFG). The treated lucernes were ensiled for $60 \mathrm{~d}$ in 2-t-capacity terylene-reinforced polyvinyl chloride bags, and then transferred into polyethylene bags each containing approximately $850 \mathrm{~g}$ dry matter (DM). After blast-freezing at $-23^{\circ}$ for $48 \mathrm{~h}$ the silages were stored at $-15^{\circ}$ until fed. The silo bag containing silage FFG split approximately $24 \mathrm{~h}$ after filling and the contents were transferred to another bag. Representative samples of the original crop and the cut crop at various stages of silage preparation and of the silages as fed were taken and freeze-dried.

\section{Animals}

Four Suffolk $\times$ Halfbred wethers, 4-5 years old and mean live weight $55 \mathrm{~kg}$ were used. Each was fitted with a rumen cannula and re-entrant cannulas in the proximal duodenum and distal ileum. They were housed individually in metabolism cages and given free access to drinking water.

\section{Experimental procedures}

The experimental design used for studying the digestion of silage $\mathrm{N}$ was a $4 \times 4$ Latin square with each period lasting 5 weeks. The sheep were given $872,827,853$ and $828 \mathrm{~g} \mathrm{DM} / \mathrm{d}$ of 
silages F, FF, FG and FFG respectively, in twenty-four equal hourly portions using automatic feeders. After a $10 \mathrm{~d}$ period of adaptation to the diets, a total faecal collection was made over $7 \mathrm{~d}$. The dilution rate of rumen fluid was then measured using a single intraruminal injection $(0.2 \mathrm{~g}$ chromium) of Cr-EDTA (Warner \& Stacey, 1968) and this was followed by measurement of the rate of volatile fatty acid (VFA) production in the rumen using a continuous $24 \mathrm{~h}$ intraruminal infusion $(4 \mu \mathrm{Ci} / \mathrm{h})$ of sodium $\left[1-{ }^{14} \mathrm{C}\right]$ acetate (Weller et al. 1967). During the fourth week, samples of strained rumen fluid were taken by suction through an indwelling sampler covered with gauze on three consecutive days and $\mathrm{pH}$, ammonia concentration, VFA concentration and casein-degrading activity (Siddons \& Paradine, 1981) measured in each sample. Ileal digesta was then collected manually over an $8 \mathrm{~h}$ period on two consecutive days. In the fifth week the rumen degradation of the four silages and of soya-bean meal and dried grass, when incubated in polyester bags (pore size $43 \mu \mathrm{m}$ ) in the rumen for 6 and $24 \mathrm{~h}$, was measured (Siddons \& Paradine, 1981; Siddons et al. 1982). Finally, duodenal digesta were collected over a $48 \mathrm{~h}$ period using automated equipment. The procedures for digesta collection and sample preparation have been described previously (Cammell, 1977). Digesta flow at the ileum and duodenum was calculated on the basis of total recovery of Cr-EDTA which, after a priming dose $(0.2 \mathrm{~g}$ $\mathrm{Cr})$, was continuously infused $(10 \mathrm{mg} \mathrm{Cr} / \mathrm{h})$ into the rumen for $5 \mathrm{~d}$ before and during the duodenal and ileal collections. $\mathrm{Na}_{2}{ }^{35} \mathrm{SO}_{4}$ was also given. An initial priming dose of $50 \mu \mathrm{Ci}$ was followed by a continuous infusion $(8 \mu \mathrm{Ci} / \mathrm{h})$ into the rumen for $24 \mathrm{~h}$ before and during the duodenal digesta collection. ${ }^{35} \mathrm{~S}$ was used to determine the proportion of microbial $\mathrm{N}$ in duodenal digesta $\mathrm{N}$ (Mathers \& Miller, 1980), the microbial fraction used for the analysis being obtained by differential centrifugation of duodenal digesta.

\section{Analytical methods}

Total $\mathrm{N}$ determinations were by a Kjeldahl digestion procedure and ammonia determinations by an automated colorimetric procedure using alkaline phenate-hypochlorite (Gehrke et al. 1968). VFA and alcohols were determined by gas-liquid chromatography, using a column packed with Chromosorb 101, and $\mathrm{Cr}$ determinations by atomic absorption spectrophotometry. Water-soluble carbohydrate content was determined by an automated ferricyanide procedure (Technicon Instrument Co. Ltd, 1969). Fresh silage was used for determining DM (Dewar \& McDonald, 1961), total N, ammonia, VFA, alcohols, lactic acid (Elsden \& Gibson, 1954) and hot-water-soluble $\mathbf{N}$ contents, whilst other silage analyses and digesta and faeces analyses were made on freeze-dried material. Silage buffer-soluble $\mathbf{N}$ content was determined by incubation of silage $(0.5 \mathrm{~g} \mathrm{DM})$ in $50 \mathrm{ml}$ buffer (McDougall, 1948 ) at $39^{\circ}$ for $1 \mathrm{~h}$. Silage non-protein-N(NPN) content was determined as the buffer-soluble $\mathrm{N}$ which was not precipitated by cold trichloroacetic acid, added to a final concentration of $50 \mathrm{~g} / \mathrm{l}$. Protein-N content was obtained as the difference between total $\mathrm{N}$ and NPN content. The susceptibility of silage $\mathrm{N}$ to digestion by proteolytic enzymes was measured by incubating silage $(0.25 \mathrm{~g} \mathrm{DM})$ for $20 \mathrm{~h}$ at $39^{\circ}$ with either $25 \mathrm{ml}$ pepsin solution $(1 \mathrm{~g}$ pepsin/l $0.1 \mathrm{M}$-hydrochloric acid) or $25 \mathrm{ml}$ protease solution (1 $\mathrm{g}$ protease (purified Type V); Sigma Chemical Co., Poole, Dorset)/litre 0.1 M-phosphate buffer, pH 7.0, containing sodium azide $(0 \cdot 1 \mathrm{~g} / \mathrm{l})$. Silage organic matter $(\mathrm{OM})$ digestibility in vitro was determined by the method of Tilley \& Terry (1963) and DM digestibility in vitro by the method of Jones \& Hayward (1975).

\section{Statistical analysis}

During period 3 one of the sheep had to be taken off the experiment when problems developed with its duodenal cannula. Thus, for this sheep, rumen and polyester bag measurements were not made in period 4 (diet FFG) and digesta collections were not made 
Table 1. Composition ( $\mathrm{g} / \mathrm{kg}$ dry matter) of lucerne (Medicago sativa) and of lucerne silages treated before ensiling with either formic acid alone $(F)$ or with formic acid and either formaldehyde $(F F)$, glutaraldehyde $(F G)$ or formaldehyde and glutaraldehyde $(F F G)$

\begin{tabular}{|c|c|c|c|c|c|}
\hline & \multirow{2}{*}{$\begin{array}{l}\text { Original } \\
\text { crop }\end{array}$} & \multicolumn{4}{|c|}{ Silage } \\
\hline & & $\mathrm{F}$ & $\mathrm{FF}$ & FG & FFG \\
\hline Dry matter (g/kg fresh) & 205 & 218 & 226 & 230 & 225 \\
\hline $\mathrm{pH}$ & - & $4 \cdot 0$ & $4 \cdot 3$ & $4 \cdot 3$ & $4 \cdot 6$ \\
\hline Organic matter & 915 & 899 & 907 & 910 & 907 \\
\hline Cellulose & 279 & 341 & 301 & 316 & 325 \\
\hline Soluble carbohydrate & 71 & 13 & 49 & 37 & 17 \\
\hline Lactic acid & - & 81 & 27 & 42 & 38 \\
\hline Acetic acid & $\ldots$ & 17 & 10 & 9 & 19 \\
\hline Propionic acid & -_ & 0 & 0 & 0 & 0.6 \\
\hline Butyric acid & - & 0 & 0 & 0 & $7 \cdot 1$ \\
\hline Methanol & - & $2 \cdot 0$ & $2 \cdot 7$ & $2 \cdot 1$ & $2 \cdot 4$ \\
\hline Ethanol & - & 7.8 & 7.7 & $7 \cdot 1$ & $11 \cdot 3$ \\
\hline Total nitrogen & $33 \cdot 0$ & $32 \cdot 0$ & 29.9 & $31 \cdot 0$ & $30 \cdot 7$ \\
\hline Ammonia-N & 0.4 & 1.7 & $1 \cdot 4$ & $1 \cdot 1$ & $2 \cdot 5$ \\
\hline Protein-N & $22 \cdot 2$ & $13 \cdot 5$ & 17.0 & $16 \cdot 7$ & $17 \cdot 7$ \\
\hline Non-protein-N & $10 \cdot 8$ & $18 \cdot 5$ & $12 \cdot 9$ & $14 \cdot 3$ & $13 \cdot 0$ \\
\hline Buffer-soluble $\mathrm{N}$ & $16 \cdot 4$ & $19 \cdot 4$ & $14 \cdot 0$ & $15 \cdot 0$ & $13 \cdot 7$ \\
\hline Hot-water-soluble $\mathrm{N}$ & $\ldots$ & $19 \cdot 2$ & $13 \cdot 5$ & $13 \cdot 6$ & $12 \cdot 6$ \\
\hline
\end{tabular}

in periods 3 and 4 . The rumen and polyester bag values for period 4 were estimated using a missing-plot technique and the results analysed by analysis of variance for a Latin square; the digesta flow values were discarded and results for the other three sheep analysed as an incomplete Latin square. To examine the effect of silage treatment on $\mathrm{N}$ and DM disappearance when the four silages were incubated in polyester bags in the rumen, a split-plot design was used, with diet as the main factor and treatment applied to the silages as the sub-factor. In all cases means were compared using Newman-Keuls' test.

\section{RESULTS}

\section{Silage characteristics}

The composition of the silages and the original crop is shown in Table 1. DM and cellulose content were slightly higher and total $\mathrm{N}$ content slightly lower in the silages than in the original crop. Compared with treatment F, treatment FF and, to a lesser extent, treatment FG reduced carbohydrate fermentation during ensiling whereas treatment FFG did not. However, the effect of treatment FFG was confounded by the silo bag bursting and the development of a clostridial-type fermentation as shown by a high ammonia content and the presence of butyric acid. Proteolysis occurred in all silages, although it was reduced by the aldehyde treatments. In the original crop, total protein- $\mathrm{N}$, soluble protein- $\mathrm{N}$ and buffer-soluble $\mathrm{N}$ accounted for $0.67,0.17$ and 0.50 of the total $\mathrm{N}$ respectively. The proportion of each fraction changed very little in the $4 \mathrm{~h}$ period between cutting and additive application when the crop lay in an undisturbed sward. With all treatments there was a decrease in the proportions of soluble protein- $\mathrm{N}$ and buffer-soluble $\mathrm{N}$ to approximately 0.07 and 0.38 respectively, in the $3 \mathrm{~h}$ period between additive application and ensiling, although total protein- $\mathrm{N}$ content and NPN content remained relatively unchanged. After $60 \mathrm{~d}$ in the silo, the propotion of the total $\mathrm{N}$ in the form of protein had decreased to 0.42 , 
Table 2. The effect of treating lucerne (Medicago sativa) with different additives* before ensiling on silage digestibility in vitro and on nitrogen disappearance during incubation for 6 and $24 \mathrm{~h}$ in polyester bags in the rumen

( $\mathrm{N}$ disappearance results are mean values for thirty-two observations)

\begin{tabular}{cccccc}
\hline Treatment* & F & FF & FG & FFG & SEM \\
\hline Digestibility in vitro: & & & & & \\
$\quad$ Dry matter & 0.64 & 0.68 & 0.63 & 0.63 & - \\
Organic matter & 0.63 & 0.63 & 0.61 & 0.57 & - \\
N Acid-pepsin & & & & & \\
$\quad$ Neutral protease & 0.84 & 0.81 & 0.80 & 0.77 & - \\
N disappearance at: & 0.80 & 0.79 & 0.80 & 0.80 & - \\
$0 \mathrm{~h}^{\dagger}$ & & & & & \\
$6 \mathrm{~h}$ & $0.74^{\mathrm{a}}$ & $0.63^{\mathrm{b}}$ & $0.61^{\mathrm{b}}$ & $0.61^{\mathrm{b}}$ & 0.009 \\
$24 \mathrm{~h}$ & $0.89^{\mathrm{a}}$ & $0.86^{\mathrm{b}}$ & $0.83^{\mathrm{c}}$ & $0.84^{\mathrm{bc}}$ & 0.008 \\
& $0.94^{\mathrm{a}}$ & $0.93^{\mathrm{b}}$ & $0.91^{\mathrm{c}}$ & $0.91^{\mathrm{c}}$ & 0.002 \\
\hline
\end{tabular}

a, b, c Mean values with different superscript letters differed significantly $(P<0 \cdot 05)$.

* For details, see Table 1 and p. 392.

$\uparrow$ Loss which occurred on washing without incubation in the rumen, mean values for four observations.

$0.57,0.54$ and 0.58 in silages $F, F F, F G$ and FFG respectively, with concomitant increases in buffer-soluble $\mathrm{N}$ and NPN.

The effects of the additives on the in vitro digestibility of the silages and on $\mathrm{N}$ disappearance when the silages were incubated in polyester bags in the rumen are shown in Table 2. The aldehyde treatments had no consistent effect on in vitro DM and OM digestibility but caused a small reduction in in vitro $\mathbf{N}$ digestibility when measured with acid-pepsin, although not when measured with neutral protease. The polyester bag measurements were made in sheep consuming the silages and statistical analysis showed no significant $(P>0.05)$ effect of type of silage consumed on $\mathrm{N}$ and DM disappearance and no significant $(P>0.05)$ interaction between diet and silage treatment. All aldehyde treatments markedly reduced $N$ loss at $0 \mathrm{~h}$, i.e. on washing, whereas after 6 and $24 \mathrm{~h}$ incubation in the rumen, $\mathrm{N}$ disappearance was high for all silages and differences between silages, although significant $(P<0.05)$, were small. Similarly, results for DM disappearance showed little or no differences between silages either on washing or after 6 and $24 \mathrm{~h}$ incubation in the rumen.

\section{Rumen measurements}

Results for rumen measurements made when the sheep were given the different silages are presented in Table 3. Silage treatment had no effect $(P>0.05)$ on rumen $\mathrm{pH}$, rumen fluid volume or rumen fluid dilution rate. Rumen ammonia levels were reduced $(P<0.05)$ by all three aldehyde treatments, with treatment FG tending to be more effective in this respect than treatments FF and FFG. Differences due to silage treatment in VFA molar proportions in the rumen, although significant $(P<0.05)$ were small, whereas total VFA concentration was markedly reduced $(P<0.05)$ by treatment FG. VFA production rate in the rumen also tended to be lower with silage FG. The type of silage given to the sheep had no effect $(P>0.05)$ on rumen casein-degrading activity nor on $N$ and DM disappearance when samples of the four silages (see Table 2), soya-bean meal or dried grass were incubated in polyester bags in the rumen for 6 and $24 \mathrm{~h}$. 
Table 3. Rumen measurements in sheep given lucerne (Medicago sativa) silages which had been treated with different additives before ensiling*

(Mean values for four sheep)

\begin{tabular}{|c|c|c|c|c|c|}
\hline Treatment ${ }^{*} \ldots$ & $\mathrm{F}$ & FF & FG & FFG & SEM \\
\hline $\mathrm{pH}$ & 6.6 & 6.7 & $6 \cdot 7$ & 6.8 & $0 \cdot 15$ \\
\hline Fluid volume (l) & 5.7 & $6 \cdot 1$ & $6 \cdot 4$ & $5 \cdot 6$ & 0.45 \\
\hline Fluid dilution rate $(/ \mathrm{h})$ & 0.06 & 0.06 & 0.07 & 0.07 & 0.010 \\
\hline Ammonia-nitrogen $(\mathrm{mg} / \mathrm{l})$ & $384^{\mathrm{a}}$ & $277^{\mathrm{b}}$ & $217^{\mathrm{b}}$ & $263^{\mathrm{b}}$ & 23.8 \\
\hline \multicolumn{6}{|l|}{ Volatile fatty acids: } \\
\hline Production rate $(\mathrm{mol} / \mathrm{d})$ & $4 \cdot 5$ & $4 \cdot 3$ & $3 \cdot 5$ & $4 \cdot 7$ & 0.43 \\
\hline Total concentration (mmol/1) & $85 \cdot 3^{\mathrm{a}}$ & $82 \cdot 5^{\mathrm{a}}$ & $68 \cdot 5^{b}$ & $73 \cdot 3^{\mathrm{ab}}$ & $2 \cdot 74$ \\
\hline \multicolumn{6}{|l|}{ Molar proportions: } \\
\hline Acetate & $0.72^{\mathrm{b}}$ & $0.70^{\mathrm{b}}$ & $0 \cdot 74^{\mathrm{ab}}$ & $0.77^{\mathrm{a}}$ & 0.009 \\
\hline Propionate & $0.22^{\mathrm{ab}}$ & $0 \cdot 24^{a}$ & $0.20^{\mathrm{ab}}$ & $0 \cdot 18^{\mathrm{b}}$ & 0.010 \\
\hline Butyrate & 0.06 & 0.06 & 0.05 & $0 \cdot 05$ & 0.003 \\
\hline $\begin{array}{l}\text { Casein-degrading activity } \\
(\mathrm{mg} \mathrm{NPN} / \mathrm{ml} \text { per } 3 \mathrm{~h})\end{array}$ & $2 \cdot 07$ & 1.69 & 1.75 & 1.93 & 0.254 \\
\hline
\end{tabular}

NPN, non-protein-N.

a. b Mean values with different superscript letters differed significantly $(P<0.05)$.

* For details, see Table 1 and p. 392.

Table 4. Organic matter (OM) digestion in sheep given lucerne (Medicago sativa) silages which had been treated with different additives before ensiling*

(Mean values for three sheep)

\begin{tabular}{|c|c|c|c|c|c|}
\hline Treatment ${ }^{*} \ldots$ & F & FF & FG & FFG & SEM \\
\hline Intake $(g / d)$ & 784 & 750 & 777 & 751 & - \\
\hline Duodenal flow $(\mathrm{g} / \mathrm{d})$ & $346^{c}$ & $388^{\mathrm{bc}}$ & $489^{a}$ & $449^{\mathrm{ab}}$ & 16.9 \\
\hline Ileal flow (g/d) & 272 & 295 & 330 & 317 & $19 \cdot 9$ \\
\hline Faecal excretion (g/d) & $212^{\mathrm{b}}$ & $263^{a}$ & $269^{a}$ & $273^{a}$ & $5 \cdot 5$ \\
\hline Apparent digestibility & $0.73^{\mathrm{a}}$ & $0.65^{b}$ & $0.65^{\mathrm{b}}$ & $0.64^{\mathrm{b}}$ & 0.007 \\
\hline \multicolumn{6}{|l|}{$\begin{array}{l}\text { Apparently digested in } \\
\text { rumen: }\end{array}$} \\
\hline $\mathrm{g} / \mathrm{d}$ & $438^{\mathrm{a}}$ & $362^{b}$ & $288^{b}$ & $302^{\mathrm{b}}$ & $16 \cdot 9$ \\
\hline $\mathrm{g} / \mathrm{kg}$ OM intake & $559^{\mathrm{a}}$ & $483^{\mathrm{ab}}$ & $370^{\mathrm{b}}$ & $403^{b}$ & $22 \cdot 6$ \\
\hline \multicolumn{6}{|l|}{$\begin{array}{l}\text { Apparently fermented in } \\
\text { rument: }\end{array}$} \\
\hline $\mathrm{g} / \mathrm{d}$ & $541^{\mathrm{a}}$ & $477^{b}$ & $417^{b}$ & $426^{\mathrm{b}}$ & $13 \cdot 7$ \\
\hline $\mathrm{g} / \mathrm{kg}$ OM intake & $691^{a}$ & $636^{\mathrm{ab}}$ & $537^{\mathrm{b}}$ & $567^{\mathrm{b}}$ & $18 \cdot 2$ \\
\hline
\end{tabular}

$a, b, c$ Mean values with different superscript letters differed significantly $(P<0 \cdot 05)$.

* For details, see Table 1 and p. 392.

+ OM apparently digested plus microbial OM flow at the duodenum calculated assuming microbes contain $10 \mathrm{~g} \mathrm{OM} / \mathrm{g}$ nitrogen.

\section{$O M$ and $N$ digestion}

$\mathrm{OM}$ and $\mathrm{N}$ flows at the duodenum and ileum were calculated assuming total recovery of infused Cr-EDTA. Faichney (1975) found that when ${ }^{51} \mathrm{Cr}$-EDTA was injected into either the rumen, abomasum or ileum, $4 \cdot 9,3 \cdot 1$ and $2 \cdot 2 \%$ respectively of the injected radioactivity were excreted in the urine. If, under the conditions of the present experiment, Cr-EDTA - absorption occurred to a similar extent then the calculated duodenal and ileal flows would overestimate true flow by approximately 2 and $3 \%$ respectively. 
Table 5. Nitrogen digestion in sheep given lucerne (Medicago sativa) silages which had been treated with different additives before ensiling*

(Mean values for three sheep)

\begin{tabular}{|c|c|c|c|c|c|}
\hline Treatment ${ }^{*} \ldots$ & $\mathbf{F}$ & FF & FG & FFG & SEM \\
\hline $\begin{array}{l}\text { Total N intake }(\mathrm{g} / \mathrm{d}) \\
\text { Duodenal flow }(\mathrm{g} / \mathrm{d}) \text { : }\end{array}$ & $27 \cdot 9$ & $24 \cdot 7$ & $26 \cdot 4$ & $25 \cdot 4$ & - \\
\hline Total N & $19 \cdot 3^{d}$ & $22 \cdot 9^{c}$ & $27 \cdot 3^{\mathrm{a}}$ & $26 \cdot 0^{\mathrm{b}}$ & 0.16 \\
\hline Non-ammonia-N (NAN) & $16 \cdot 9^{\mathrm{c}}$ & $21 \cdot 3^{b}$ & $24 \cdot 9^{\mathrm{a}}$ & $23 \cdot 6^{\mathrm{a}}$ & $0 \cdot 31$ \\
\hline Microbial N & $10 \cdot 3$ & 11.5 & $13 \cdot 0$ & $12 \cdot 4$ & 0.45 \\
\hline $\begin{array}{l}\text { Efficiency of microbial } \mathrm{N} \\
\text { synthesis }(\mathrm{g} / \mathrm{kg} \text { OMADR) }\end{array}$ & $24 \cdot 4^{\mathrm{b}}$ & $32 \cdot 2^{\mathrm{ab}}$ & $46 \cdot 6^{\mathrm{a}}$ & $42 \cdot 3^{a b}$ & $3 \cdot 23$ \\
\hline $\begin{array}{l}\text { Silage } N \text { degradability } \\
\text { in the rumen } \dagger\end{array}$ & $0.82^{a}$ & $0 \cdot 67^{\mathrm{b}}$ & $0 \cdot 60^{\mathrm{c}}$ & $0.62^{\mathrm{c}}$ & 0.007 \\
\hline Ileal NAN flow (g/d) & $8 \cdot 1$ & $9 \cdot 8$ & $9 \cdot 6$ & $9 \cdot 4$ & 0.30 \\
\hline $\begin{array}{l}\text { NAN apparently digested in } \\
\text { small intestine }(\mathrm{g} / \mathrm{d})\end{array}$ & $8 \cdot 8^{\mathrm{c}}$ & $11 \cdot 4^{b}$ & $15 \cdot 3^{\mathrm{a}}$ & $14 \cdot 2^{\mathrm{a}}$ & 0.35 \\
\hline $\begin{array}{l}\text { NAN apparent digestibility in } \\
\text { small intestine }\end{array}$ & $0.52^{\mathrm{b}}$ & $0.54^{\mathrm{ab}}$ & $0.61^{\mathrm{a}}$ & $0.61^{\mathrm{a}}$ & 0.015 \\
\hline Faecal $N$ excretion $(g / d)$ & $5 \cdot 1^{\mathrm{B}}$ & $7 \cdot 6^{\mathrm{a}}$ & $7 \cdot 7^{\mathrm{a}}$ & $7 \cdot 6^{\mathrm{a}}$ & 0.15 \\
\hline $\begin{array}{l}\text { Apparent digestibility of } \mathrm{N} \\
\text { in whole tract }\end{array}$ & $0.82^{\mathrm{a}}$ & $0.69^{b}$ & $0.71^{\mathrm{b}}$ & $0.70^{\mathrm{b}}$ & 0.005 \\
\hline
\end{tabular}

OMADR, organic matter apparently digested in the rumen.

a, b, c Mean values with different superscript letters differed significantly $(P<0.05)$.

* For details, see Table 1 and p. 392.

+ Undegraded silage $N$ calculated as the difference between the total NAN flow at the duodenum and the microbial $\mathrm{N}$, less $1.5 \mathrm{~g} / \mathrm{d}$ endogenous NAN.

OM digestion in the rumen, small intestine and large intestine is shown in Table 4. There was a significant $(P<0.05)$ reduction in the amount $(\mathrm{g} / \mathrm{d})$ of OM apparently digested or fermented in the rumen when the aldehyde-treated silages were given, although when expressed per unit OM intake the effect of treatment FF was not significant $(P>0.05)$. Similarly, OM flow at the duodenum was increased by all aldehyde treatments but the difference was significant $(P<0.05)$ only with treatments FG and FFG. More OM was apparently digested in the small intestine with the aldehyde-treated silages and consequently ileal OM flows, although tending to be increased by aldehyde treatment, did not differ significantly $(P>0.05)$ between silages. Faecal $O M$ excretion was increased $(P<0.05)$ by all aldehyde treatments and, in contrast to the finding with in vitro procedures (Table 2), the apparent digestibility of $\mathrm{OM}$ in the whole tract was reduced $(P<0.05)$.

The effect of silage treatment on $\mathrm{N}$ digestion is shown in Table 5. All three aldehyde treatments increased $(P<0.05)$ non-ammonia-N (NAN) flow at the duodenum due to a non-significant $(P>0.05)$ increase in microbial $\mathrm{N}$ flow and to a significant $(P<0.05)$ decrease in the proportion of silage $N$ degraded in the rumen. Both the increase in NAN flow and the decrease in silage $\mathrm{N}$ degradability were greater $(P<0.05)$ with silages $\mathrm{FG}$ and FFG than with silage FF. Whereas with silage $F$ there was a large net loss $(8.6 \mathrm{~g} / \mathrm{d})$ of $\mathrm{N}$ between mouth and duodenum, the loss was much less $(1.8 \mathrm{~g} / \mathrm{d})$ with silage $F F$, and with silages FG and FFG, $\mathrm{N}$ flow at the duodenum was slightly higher than $\mathrm{N}$ intake. The small increase $(P<0.05)$ in microbial $\mathrm{N}$ flow at the duodenum when the aldehyde-treated silages were given, coupled with the reduction $(P<0.05)$ in the amount of OM apparently digested in the rumen (Table 4$)$, resulted in a significant $(P<0.05)$ increase in the efficiency of microbial $\mathrm{N}$ synthesis when silage $\mathrm{FG}$ was given and non-significant $(P>0.05)$ increase when silages FF and FFG were given. The amount of NAN apparently absorbed from 
the small intestine was increased $(P<0.05)$ by all aldehyde treatments but to a greater $(P<0.05)$ extent by treatments FG and FFG. The two glutaraldehyde-containing additives also increased $(P<0.05)$ the apparent digestibility of NAN in the small intestine, whereas treatment FF did not. The amount of NAN at the ileum did not differ significantly $(P>0.05)$ between silages, although it tended to be higher with the aldehyde-treated silages. Faecal $\mathrm{N}$ excretion was significantly $(P<0.05)$ increased and the apparent digestibility of $\mathrm{N}$ in the whole tract significantly $(P<0.05)$ decreased by all aldehyde treatments.

\section{DISCUSSION}

Satisfactory assessment of the effect of the aldehyde mixture, i.e. treatment FFG, on silage fermentation quality was not possible because of the confounding effect of the silo bag bursting and the development of a clostridial-type fermentation. It is not possible to conclude that the latter was definitely due to the silo bag bursting, although it was the most likely reason. Apart from silage FFG, the silages were of good quality, according to the criteria defined by Demarquilly \& Dulphy (1977). In agreement with the findings of Wilson \& Jordan (1982), both formaldehyde and glutaraldehyde reduced the extent to which soluble carbohydrate and protein were degraded during ensiling. Formaldehyde was more effective than glutaraldehyde in restricting carbohydrate fermentation, whereas the two aldehydes were equally effective in restricting protein degradation. However, the protein content of all silages was lower than that of the original crop and, with all treatments, protein breakdown occurred within the silo and not during the time (approximately $7 \mathrm{~h}$ ) which elapsed between cutting and completion of ensiling. In other studies (Brady, 1960; Carpintero et al. 1979) it has been found that proteolysis, which is mainly due to the action of plant proteases, is minimal during a short wilt, and that treatment with formic acid slows down rather than prevents protein breakdown in the silo. In the present study, soluble protein content did decrease between additive application and completion of ensiling but this was probably due to precipitation by formic acid since it occurred to a similar extent with all treatments and was not accompanied by an increase in NPN content. The presence of formic acid in all additives may also explain the absence of a more rapid reaction between glutaraldehyde and protein than between formaldehyde and protein, as observed by Mangan et al. (1980), because aldehyde-protein bonds are less stable at low pH (Ferguson et al. 1967).

The in vitro and polyester bag procedures used to examine the effect of aldehyde treatment on silage digestibility and rumen degradability gave results differing from those observed in vivo. Thus there was no consistent effect of the aldehydes on silage digestibility in vitro, whereas $\mathrm{OM}$ and $\mathrm{N}$ digestibility in vivo were depressed by all aldehyde treatments. Similarly, although the aldehydes reduced silage soluble- $\mathrm{N}$ content, differences between silages in $\mathrm{N}$ disappearance after 6 or $24 \mathrm{~h}$ incubation in polyester bags in the rumen were very small, whereas $\mathrm{N}$ degradability in the rumen, and also rumen ammonia concentration, were reduced by all aldehyde treatments, and more by glutaraldehyde than formaldehyde. In the polyester-bag study, $\mathrm{N}$ loss on washing most closely approximated the $\mathrm{N}$ degradability values estimated in vivo and, for each silage, $\mathrm{N}$ disappearance after only $6 \mathrm{~h}$ incubation in the rumen was higher than the in vivo $\mathbf{N}$ degradability estimate. Unexpectedly high $\mathrm{N}$ losses during incubation of formaldehyde-treated silage in polyester bags in the rumen have been found in other studies (Brett et al. 1981; Siddons et al. 1982).

Both formaldehyde and glutaraldehyde possess antimicrobial properties which, whilst of potential benefit during ensiling, could be harmful in the rumen. Mangan et al. (1980) observed reduced microbial motility in the rumen when cattle were given formaldehydetreated lucerne but not when they were given glutaraldehyde-treated lucerne. An adverse 
effect of formaldehyde-treated silage on rumen microbes, as evidenced by a decreased microbial $\mathrm{N}$ flow at the duodenum, was also found in the study of Beever et al. (1977), although this did not occur in other studies (Siddons et al. 1979; Thomson et al. 1981; Overend \& Armstrong, 1982). In the present study, assessment of microbial degradative activity in the rumen in terms of the casein-degrading activity or the rate of degradation of different feedstuffs when incubated in polyester bags in the rumen, indicated no effect of the aldehydes on the inherent digestive ability of the rumen microbes. Microbial $\mathrm{N}$ flow at the duodenum was also unaffected by the aldehyde treatments and, since OM digestion in the rumen was reduced, the efficiency of microbial $\mathrm{N}$ synthesis was increased, especially when silage FG was given. Possible reasons for this could include: a difference in the nature of the OM digested, i.e. the aldehyde-treated silages having a higher soluble-carbohydrate content and a lower fermentation acid and degradable protein content; a more continuous supply of peptides and amino acids, although this is less likely to be so important with hourly feeding; a change in the microbial flora; or a increased flow of particulate matter from the rumen increasing the flow of particle-bound bacteria.

Glutaraldehyde reduced $O M$ fermentation in the rumen to a greater extent than formaldehyde and also depressed VFA production, whereas formaldehyde did not. Consequently, the amount of VFA produced (mol) per $\mathrm{kg} \mathrm{OM}$ fermented was similar for silage $F(8 \cdot 3)$ and $F G(8 \cdot 4)$, slightly higher for silage $F F(9 \cdot 0)$ and for some unknown reason considerably higher for silage FFG (11.0). The reduction in rumen OM fermentation can only partly be attributed to the ability of the aldehydes to protect silage protein from degradation in the rumen (silage NAN degraded in the rumen $\times 6.25$ being reduced from $133 \mathrm{~g} / \mathrm{d}$ with silage $\mathrm{F}$ to 95,94 and $85 \mathrm{~g} / \mathrm{d}$ with silage $\mathrm{FF}, \mathrm{FG}$ and FFG respectively), suggesting that the rumen digestion of dietary components other than protein was reduced by aldehyde treatment. A similar conclusion regarding the effect of formaldehyde was reached by Miller (1972). Since this would not appear to have been due to an adverse effect of the aldehydes on the degradative ability of the rumen microbes it presumably reflected a decreased susceptibility of dietary components to microbial attack, although this was not evident in terms of a reduced rate of DM disappearance when the silages were incubated in polyester bags in the rumen.

The overall effects of the three aldehyde treatments on silage $\mathrm{N}$ digestion were generally similar to previous findings with formaldehyde. Thus the apparent digestibility of $\mathrm{N}$ in the whole tract and $\mathrm{N}$ degradability in the rumen were decreased, whilst NAN flow into and net absorption from the small intestine increased. The increase in net NAN absorption from the small intestine was greater with glutaraldehyde than with formaldehyde, due partly to an increase in silage $\mathrm{N}$ escaping degradation in the rumen and partly to an increase in the apparent digestibility of NAN in the small intestine which did not occur with formaldehyde. In other studies the apparent digestibility of protein (NAN) in the small intestine has been found to be reduced by formaldehyde treatment of silage (Beever et al. 1977), unaffected (Siddons et al. 1979) or increased (Overend \& Armstrong, 1982). However, when treatments alter the amount of protein entering the small intestine then unless endogenous protein at the ileum is a fixed proportion of the amount entering the small intestine, comparisons on an apparent digestibility basis may be misleading in terms of treatment effects on true digestibility.

Despite the evidence from this and other digestion studies that formaldehyde treatment of silages can increase net protein absorption from the small intestine, production studies have been less convincing in demonstrating a beneficial effect of formaldehyde treatment of silage (see Kaiser, 1979). In simple-stomached animals, formaldehyde treatment has been found to reduce protein digestibility and also the efficiency of utilization of absorbed protein (Hove \& Lohrey, 1976; Kowalczyk \& Otwinowska, 1983). If this is so in ruminants given 
aldehyde-treated silage then benefits will occur only if the increase in protein supply to the small intestine more than offsets any decrease in the biological value of the protected protein. In terms of increasing net protein absorption from the small intestine, glutaraldehyde was superior to formaldehyde, although it also reduced OM digestion in the rumen to a greater extent which might adversely affect total DM intake. Its effect, if any, on the efficiency of utilization of absorbed protein is not known, although Mangan et al. (1980) reported that both formaldehyde and glutaraldehyde reduced the nutritional value of casein and leaf protein.

The authors thank Mr A. R. Austin for the surgical preparation of the sheep, Mr J. Paradine, Miss A. Thirkell and Mr R. T. Evans for technical assistance and Mr M. S. Dhanoa for his help with statistical analysis. The Grassland Research Institute is financed through the Agricultural and Food Research Council and the work formed part of a commission from the Ministry of Agriculture, Fisheries and Food.

\section{REFERENCES}

Beever, D. E., Thomson, D. J., Cammell, S. B. \& Harrison, D. G. (1977). Journal of Agricultural Science, Cambridge 88, 61-70.

Brady, C. J. (1960). Journal of the Science of Food and Agriculture 11, 276-284.

Brett, P. A., Dowson, S. \& Armstrong, D. G. (1981). Proceedings of the 6th Silage Conference, Edinburgh. pp. 21-22.

Cammell, S. B. (1977). Technical Report no. 24. Hurley: Grassland Research Institute.

Carpintero, C. M., Henderson, A. R. \& McDonald, P. (1979). Grass and Forage Science 34, 311-315.

Chamberlain, D. G., Thomas, P. C. \& Wait, M. K. (1982). Grass and Forage Science 37, 159-164.

Demarquilly, C. \& Dulphy, J. P. (1977). Proceedings of the International Meeting on Animal Production from Temperate Grassland, Dublin. pp. 53-61.

Dewar, W. A. \& McDonald, P. (1961). Journal of the Science of Food and Agriculture 12, 790-795.

Elsden, S. R. \& Gibson, Q. H. (1954). Biochemical Journal 58, 154-158.

Faichney, G. J. (1975). Australian Journal of Agricultural Research 26, 319-327.

Ferguson, K. A., Hemsley, J. A. \& Reis, P. J. (1967). Austratian Journal of Science 30, 215-217.

Gehrke, G. W., Kaiser, F. E. \& Ussary, J. P. (1968). Journal of the Association of Official Analytical Chemists 51, 200-211.

Hove, E. L. \& Lohrey, E. (1976). Journal of Nutrition 106, 382-387.

Jones, D. I. H. \& Hayward, M. V. (1975). Journal of the Science of Food and Agriculture 26, 711-718.

Kaiser, A. G. (1979). The effects of formaldehyde application at ensiling on the utilisation of silage by young growing cattle. Ph.D thesis, Reading University.

Kowalczyk, J. \& Otwinowska, A. (1983). Zeitschrift fur Tierphysiologie, Tierernahrung und Futtermittelkunde 49, $38-42$.

McDougall, E. I. (1948). Biochemical Journal 43, 99-109.

Mangan, J. L., Jordan, D. J., West, J. \& Webb, P. J. (1980). Journal of Agricultural Science, Cambridge 95, 603-617.

Mathers, J. C. \& Miller, E. L. (1980). British Journal of Nutrition 43, 503-514.

Miller, E. L. (1972). Proceedings of the Nutrition Society 31, 27A.

Overend, M. A. \& Armstrong, D. G. (1982). Occasional Publication of the British Society of Animal Production no. 6, 162-163.

Siddons, R. C., Beever, D. E. \& Kaiser, A. G. (1982). Journal of the Science of Food and Agriculture 33, 609-613.

Siddons, R. C., Evans, R. T. \& Beever, D. E. (1979). British Journal of Nutrition 42, 535-545.

Siddons, R. C. \& Paradine, J. (1981). Journal of the Science of Food and Agriculture 32, 973-981.

Technicon Instruments Co. Ltd (1969). Technicon Methodology Sheet N9 B. Basingstoke: Technicon Instruments Co. Ltd.

Thomson, D. J., Beever, D. E., Lonsdale, C. R., Haines, M. J., Cammell, S. B. \& Austin, A. R. (1981). British Journal of Nutrition 46, 193-207.

Tilley, J. M. A. \& Terry, R. A. (1963). Journal of the British Grassland Society 18, 104-111.

Waldo, D. R., Keys, J. E., Smith, L. W. \& Gordon, C. H. (1971). Journal of Dairy Science 54, 77-84.

Warner, A. C. I. \& Stacey, B. D. (1968). British Journal of Nutrition 22, 369-387.

Weller, R. A., Gray, E. V., Pilgrim, A. F. \& Jones, G. B. (1967). Australian Journal of Agricultural Research 18, $107-115$. 
Wilkins, R. J., Wilson, R. F. \& Woolford, M. K. (1974). Proceedings of the 5th General Meeting of the European Grassland Federation, Uppsala, Vaxtodling 29, 197-201.

Wilkinson, J. M., Wilson, R. F. \& Barry, T. N. (1976), Outlook on Agriculture 9, 3-8.

Wilson, R. F. \& Jordan, D. J. (1982). Occasional Publication of the British Society of Animal Production no. 6, 183-184.

Wilson, R. F., Wilkins, R. J. \& Cook, J. E. (1974). Proceedings of the 12th International Grassland Congress, Moscow 3, 674-690. 